\title{
RADIOCARBON DATES FOR LAVA FLOWS FROM NORTHEAST RIFT ZONE OF MAUNA LOA VOLCANO, HILO 71/2' QUADRANGLE, ISLAND OF HAWAII
}

\section{J M BUCHANAN-BANKS*, J P LOCKWOOD** and MEYER RUBIN ${ }^{\dagger}$}

\section{INTRODUCTION}

Twenty-eight ${ }^{14} \mathrm{C}$ analyses are reported for carbonized roots and other plant material collected from beneath 15 prehistoric lava flows erupted from the northeast rift zone (NERZ) of Mauna Loa Volcano (ML) utilizing the recovery techniques of Lockwood and Lipman (1980). Most samples were collected from the Hilo $71 / 2^{\prime}$ quadrangle during field work for a geologic map of that quadrangle (Buchanan-Banks, unpub data); a few sample sites are located in adjacent quadrangles: Piihonua to the west and Mountain View to the south. Altitudes are given in English units as well as metric to facilitate locating sites on USGS topographic maps.

The new ${ }^{14} \mathrm{C}$ dates establish ages for 13 previously undated lava flows, and correct or add to information previously reported by Kelley et al (1979) and Rubin, Gargulinski and McGeehin (1987). Limiting ages on other flows that lie either above or below the dated flows are also established. These dates help to unravel the eruptive history of ML's NERZ, and they extend that history back ca 24,000 yr. Although 9 eruptions have occurred from vents along the NERZ during the period of written history (the past $140 \mathrm{yr}$ ) (Peterson \& Moore, 1987, Table 7.4), only lava flows from the 1880-81 eruption entered the Hilo quadrangle. During the past $2000 \mathrm{yr}$, at least 7 ML lava flows entered the quadrangle (averaging 1 lava flow about every $285 \mathrm{yr}$ ) and at least 1 reached the sea (Buchanan-Banks, unpub data). The recurrence interval is defined more poorly for earlier periods because more of the older flows are covered by younger eruptive material, and many of the few small outcrops that remain are commonly obscured by agriculture and construction projects.

The new ${ }^{14} \mathrm{C}$ ages also establish time constraints for tephra, probably mostly erupted from Mauna Kea Volcano, deposited in and near the quadrangle. The oldest documented ash deposit lies beneath a pahoehoe flow stratigraphically dated by $\mathrm{W}-5075$ ca $24,000 \mathrm{yr}$; an ash also lies between a pahoehoe flow ca 24,000 yr old (W-4890) and another ca 14,000 yr old (W-4621, -4971, -4973, -4620, -4977); a more recent ash overlies a pahoehoe flow $<\mathrm{ca} 10,000 \mathrm{yr}$ old (W-5072). These ash deposits likely represent all ash falling in a given area over a long time span rather than individual eruptive events. Although tephra occurs between other younger ML lava flows, it is difficult to tell if the deposits are airfall layers or have been reworked by wind and water.

All charcoal samples were analyzed at the USGS Radiocarbon Labora98661

* US Geological Survey (USGS), 5400 MacArthur Boulevard, Vancouver, Washington

** USGS, Hawaiian Volcano Observatory, PO Box 51, Hawaii Volcanoes National Park, Hawaii 96718

+ USGS, National Center, MS 971, Reston, Virginia 22092 
tory at Reston. The samples were converted to acetylene gas and their ${ }^{14} \mathrm{C}$ activity was measured in 3 different proportional gas counters. Pretreatment of samples consisted of mechanical removal of carbonaceous contaminants by picking under magnification, heating in hydrochloric acid, heating in a basic $(\mathrm{NaOH})$ solution, and heating in acid again. Distilled water rinses followed each stage. The $\mathrm{NaOH}$ treatment was omitted in the case of very small samples $(<3 \mathrm{~g}$ of charcoal) for fear of losing the entire sample. The error quoted is the standard $1 \sigma$ counting error and does not take into account other known laboratory uncertainties that could double this figure. No attempt was made to estimate the effect of juvenile, non-radiogenic carbon as none of the samples are believed to have been close to volcanic gas vents (Rubin, Lockwood \& Friedman, 1987). The ages, given in yr BP (1950), were not corrected to a calendar date by the tree-ring calibrations presently available.

Only 3 of the 27 charcoal samples collected gave anomalous ages (indicated by sample number in parenthesis) and 2 of these ages were subsequently corrected through recollection of charcoal and new analyses (W4535 by -5098 , and $\mathrm{W}-4894$ by -5072 and -5075$)$. Charcoal could not be recollected for $\mathrm{W}-5081$; hence, the remainder of the existing sample was re-analyzed as W-5604. No substantive decrease in the age was obtained.

\section{SAMPLE DESCRIPTIONS}

\section{(W-4535). Pahoehoe flow of Kulaloa Rd}

Charcoal roots at top of soil beneath finely crystalline pahoehoe flow; coll in drainage ditch $10 \mathrm{~m} \mathrm{~S}$ of Ainaola Dr and $100 \mathrm{~m}$ E of Kulaloa Rd junction, alt $1105 \mathrm{ft}(337 \mathrm{~m})$ Piihonua quad $\left(19^{\circ} 38.52^{\prime} \mathrm{N}, 155^{\circ} 07.58^{\prime} \mathrm{W}\right)$. Coll 1979 by J P Lockwood (JPL). Comment (JPL): date is impossibly young, judging from degree of weathering and directions of remanent magnetization obtained on flow (Holcomb, Champion \& McWilliams, 1986, site ID 9B061). See W-5098 for correct date.

\section{W-5098. Pahoehoe flow of Kulaloa Rd}

$$
570 \pm 60
$$

Charcoal fragments in thin ash pockets beneath pahochoe flow at contact with underlying aa flow (picrite of Panaewa Forest Reserve, W-4981); coll $150 \mathrm{~m} \mathrm{NW}$ of $S$ end of Kulaloa Rd, in dense thicket of guava and other exotic brush, alt $1580 \mathrm{ft}(482 \mathrm{~m})$, Piihonua quad $\left(19^{\circ} 37.62^{\prime} \mathrm{N}, 155^{\circ} 08.46^{\prime}\right.$ W). Coll 1981 by J P and B M Lockwood. Comment (JPL): dates youngest prehistoric lava flow in Hilo quad.

\section{W-4631. Pahoehoe flow of Kukuau ahupuaa $1110 \pm 60$}

Charcoal rootlets beneath pahochoe flow of Kukuau ahupuaa (ahupuaa is Hawaiian land unit usually extending from uplands to sea) at top of thin stream deposit overlying aa flow of Ainaola Dr, W-5599; coll on NW side of Waiakea Stream, due W of Univ Hawaii, Hilo, alt $140 \mathrm{ft}(43 \mathrm{~m})$ Hilo quad $\left(19^{\circ} 42.38^{\prime} \mathrm{N}, 155^{\circ} 05.16^{\prime} \mathrm{W}\right)$. Coll 1979 by J M Buchanan-Banks (JMBB). Comment (JMBB): sample dates second youngest and most exten- 
sive prehistoric pahoehoe flow in NW part of quad. Flow originated from vents at ca $9000 \mathrm{ft}(2745 \mathrm{~m})$ elev (J P Lockwood, pers commun, 1986).

W-5597. Pahoehoe flow of Kukuau ahupuaa

$1140 \pm 300$

Charcoal fragments dispersed in stream deposit under pahoehoe flow; coll in N tributary of Alenaio Stream, $400 \mathrm{~m} \mathrm{E}$ of Komohana St, alt $135 \mathrm{ft}$ $(41 \mathrm{~m})$, Hilo quad $\left(19^{\circ} 42.99^{\prime} \mathrm{N}, 155^{\circ} 05.74^{\prime} \mathrm{W}\right)$. Coll 1979 by J M Buchanan-Banks. Comment (JMBB): sparse charcoal scattered within stream deposit may have been reworked by floods. However, directions of remanent magnetization determined on samples coll from flow agree well with ${ }^{14} \mathrm{C}$ age. From same flow as $\mathrm{W}-4631$.

\section{W-4343. Pahoehoe flow of Kukuau ahupuaa}

$1280 \pm 70$

Charcoal rootlets and one large root of ca $2 \mathrm{~cm}$ diam, coll at base of pahoehoe flow at contact with thin soil overlying aa rubble, $40 \mathrm{~m} \mathrm{~W}$ of Ainaola Dr-Hoaka Rd intersection, N of Hoaka Rd and W along unpaved road, then $\mathrm{N}$ again at plant nursery entrance, on $\mathrm{W}$ side of road, alt $769 \mathrm{ft}$ (234m), Hilo quad $\left(19^{\circ} 40.18^{\prime} \mathrm{N}, 155^{\circ} 07.33^{\prime} \mathrm{W}\right)$. Coll 1978 by J P Lockwood and J M Buchanan-Banks. Comment (JMBB): age agrees well with both W-4631 and -5597 .

\section{W-4981. Picritic aa flow of Panaewa Forest Reserve}

$1470 \pm 50$

Charcoal rootlets from unoxidized, coarse, grayish-black basal aa rubble surrounded by red oxidized aa; coll in new quarry cut on NW edge of Allied Aggregates Quarry, W of hwy 11, 1.6km N from Keaau turnoff, alt $360 \mathrm{ft}(110 \mathrm{~m})$, Hilo quad $\left(19^{\circ} 38.56^{\prime} \mathrm{N}, 155^{\circ} 03.39^{\prime} \mathrm{W}\right)$. Coll 1981 by J P Lockwood. Comment (JPL): first reliable date for widespread surface flow in Hilo quad erupted from vents at $5200 \mathrm{ft}(1585 \mathrm{~m})$ elev on NERZ. Supersedes problematically old date of $2890 \pm 70 \mathrm{yr}$ (Kelley et al, 1979: W-41 74) from beneath same flow.

\section{W-5670. Pahoehoe flow of Waiakea Stream}

$1500 \pm 200$

Charcoal roots at top of ash deposit beneath hypersthene-bearing pahochoe flow, alt $780 \mathrm{ft}(238 \mathrm{~m}), 250 \mathrm{~m}$ from W edge of Hilo quad $\left(19^{\circ}\right.$ $39.90^{\prime} \mathrm{N}, 155^{\circ} 07.32^{\prime} \mathrm{W}$ ). Coll 1985 by J M Buchanan-Banks. Comment (JMBB): sample dates previously unrecognized young flow beneath pahoehoe flow of Kukuau ahupuaa (W-4631, -5597, -4343). At colln site, ash overlies another pahoehoe unit.

\section{W-5278. Pahoehoe flow of Waiakea Stream}

$1740 \pm 100$

Carbonized twigs and roots, up to $2 \mathrm{~cm}$ diam, coll from contact between thin outcrop of pahochoc and top of thin ash unit; coll in NW bank of Waiakea Stream, alt $760 \mathrm{ft}(232 \mathrm{~m}), 1.2 \mathrm{~km} \mathrm{E}$ of W edge of Hilo quad $\left(19^{\circ} 40.20^{\prime} \mathrm{N}, 155^{\circ} 06.85^{\prime} \mathrm{W}\right)$. Coll 1983 by J M Buchanan-Banks. Comment (JMBB): comparison of thin section from this flow and from that dated by $\mathrm{W}-5670$ suggests that they are same unit. Site destroyed by stream-widening work to reduce flood hazard. 
W-4621. Pahoehoe flow of Punahoa ahupuaa

Charcoal root, ca $2 \mathrm{~cm}$ diam, beneath pahoehoe flow at top of ash layer $\geqq 1 \mathrm{~m}$ thick; coll on NW side of Kaumana Dr in front of house \#698, alt $570 \mathrm{ft}(174 \mathrm{~m}), 800 \mathrm{~m} \mathrm{E}$ of W edge of Hilo quad $\left(19^{\circ} 42.28^{\prime} \mathrm{N}, 155^{\circ} 07.02^{\prime}\right.$ W). Coll 1979 by J M Buchanan-Banks and N G Banks. Comment (JMBB): probable $S$ extension of flow dated $4050 \pm 50 \mathrm{yr}$ (Kelley et al, 1979: W3803); sample helps distinguish this flow from younger pahoehoe of Kukuau ahupuaa that overlies it to $\mathrm{E}$.

W-4629. Pahoehoe flow of Punahoa ahupuaa

$3360 \pm 80$

Abundant charcoal roots, some as much as $2 \mathrm{~cm}$ diam, beneath pahoehoe flow at top of ash layer $\geqq 3 \mathrm{~m}$ thick; coll in Waipahoehoe Stream, alt $710 \mathrm{ft}(214 \mathrm{~m}), \mathrm{W}$ edge of Hilo quad $\left(19^{\circ} 41.87^{\prime} \mathrm{N}, 155^{\circ} 07.49^{\prime} \mathrm{W}\right)$. Coll by J M Buchanan-Banks. Comment (JMBB): age agrees well with W-4621 and -4624 from beneath same flow. At colln site, flow is overlain by thin soil and by 1880-81 pahoehoe; flow also overlies thick ash and older pahoehoe dated by $\mathrm{W}-4890$.

\section{W-4624. Pahoehoe flow of Punahoa ahupuaa}

$3380 \pm 80$

Carbonized part of trunk or root found in pahoehoe flow in sealed tree mold exposed during construction of Wailuku-Alenaio diversion canal; coll $\mathrm{N}$ of Waianuenue Ave, on E side of canal, alt $855 \mathrm{ft}(261 \mathrm{~m})$, Piihonua quad $\left(19^{\circ} 43.0^{\prime} \mathrm{N}, 155^{\circ} 08.15^{\prime} \mathrm{W}\right)$. Coll 1979 by J M Buchanan-Banks and $\mathrm{N}$ G Banks. Comment (JMBB): age agrees well with W-4621 and -4629 from beneath same flow further E. Several units of this flow are exposed in canal, overlying ash of variable thickness and locally exposed pahoehoe probably dated by W-4971, $-4973,-4620,-4977$.

(W-5604). $3450 \pm 200$

(W-5081).

$3920 \pm 80$

Charcoal roots and fragments distributed in vertical crack in pahoehoe flow and in pockets at contact with underlying alluvium; coll from $\mathrm{S}$ bank of Alenaio Stream, immediately W of Komohana St, alt $237 \mathrm{ft}(72 \mathrm{~m})$, Hilo quad $\left(19^{\circ} 42.83^{\prime} \mathrm{N}, 155^{\circ} 05.93^{\prime} \mathrm{W}\right)$. Coll 1979 by J M Buchanan-Banks. Comment (JMBB): unusual location of charcoal in crack aroused skepticism about obtaining true age. Anomalously old age of W-5081 led to re-analysis of remainder of same charcoal as W-5604 but age still is considered too old. Charcoal was probably eroded from beneath older lava upstream and redeposited by flooding, as site is drainage bottleneck. Additional field mapping and determinations of remanent magnetization on overlying lava indicate it correlates with $1880-81$ pahoehoe. Site now covered by masonry retaining wall.

\section{W-5077. Pahoehoe flow of Wilder Rd}

$4410 \pm 120$

Carbonized mat of vegetation coll at top of $2 \mathrm{~m}$-thick ash beneath and at edge of pahoehoe flow, S of Kaumana Dr, 800m SE along Edita Dr, 200 $\mathrm{m}$ E of rd along amorphous stream channel, alt $600 \mathrm{ft}$ (183m), Hilo quad 
$\left(19^{\circ} 41.40^{\prime} \mathrm{N}, 155^{\circ} 07.18^{\prime} \mathrm{W}\right)$. Coll 1983 by J M Buchanan-Banks. Comment ( JMBB): sample dates relatively young prehistoric flow in $\mathrm{W}$ part of quad; flow is locally overlain by $1880-81$ pahoehoe.

\section{W-4536. Aa flow of Puna Sugar fields}

$5250 \pm 100$

Large charcoal root at top of yellowish-red ash beneath picritic aa flow; coll 2.2km SE of Keaau, just NE of Keaau-Pahoa Rd, alt $320 \mathrm{ft}(98 \mathrm{~m})$, Mountain View quad (19 36.66 $\left.\mathrm{N}, 155^{\circ} 01.92^{\prime} \mathrm{W}\right)$. Coll 1979 by J P Lockwood. Comment (JPL): sample dates extensive picritic aa flow with minor pahoehoe phases now under sugar-cane cultivation in Keaau area. Flow probably derived from Puu Makaala (Puu Makaala quad, 3700ft (1128m) elev). Contact, $5 \mathrm{~m}$ below surface, was temporarily exposed by 1979 floodwater gullying.

\section{W-5599. Aa flow of Ainaola Dr}

$7230 \pm 230$

Charcoal in discontinuous pockets at top of ash layer beneath olivinebearing aa flow; coll from $\mathrm{N}$ bank at $\mathrm{E}$ end of stream flowing through municipal golf course, W of bridge, $300 \mathrm{~m} \mathrm{~N}$ of Haihai St and $400 \mathrm{~m} \mathrm{~W}$ of Kinoole St, alt $225 \mathrm{ft}(69 \mathrm{~m})$, Hilo quad $\left(19^{\circ} 40.79^{\prime} \mathrm{N}, 155^{\circ} 04.50^{\prime} \mathrm{W}\right)$. Coll 1984 by J M Buchanan-Banks and V C Taylor. Comment (JMBB): sample dates widespread olivine-bearing aa flow in W-central part of Hilo, and establishes min age for undated flows beneath it.

\section{W-4975. Aa flow of Malaai Rd}

$9020 \pm 130$

Charcoal rootlets in thin ash beneath picritic aa flow; coll in SE bank Waiakea Stream, alt $920 \mathrm{ft}(280 \mathrm{~m}), 0.32 \mathrm{~km} \mathrm{~W}$ of E edge of Piihonua quad $\left(19^{\circ} 39.62^{\prime} \mathrm{N}, 155^{\circ} 07.68^{\prime} \mathrm{W}\right)$. Coll 1981 by J P Lockwood. Comment (JPL): sample dates picritic aa flow beneath aa of Ainaola Dr (W-5599); former is distinguished by its more abundant olivine. However, both flows may be part of same eruption cycle based on similarities of morphology and mineral content.

W-4884. Pahoehoe flow of Waiakea Homestead

$9780 \pm 140$

Charcoal tree root at top of ash beneath plagioclase-phyric pahoehoe flow; coll $1 \mathrm{~km} \mathrm{~S}$ of Ainaola Rd along Alaloa Rd, to E in S bank of stream, alt $660 \mathrm{ft}(201 \mathrm{~m})$, Hilo quad (19 $\left.39.52^{\prime} \mathrm{N}, 155^{\circ} 06.05^{\prime} \mathrm{W}\right)$. Coll 1980 by J M Buchanan-Banks. Comment ( JMBB): sample provides important date on previously unrecognized flow from NERZ; it also establishes min age for several underlying flows.

W-5072. Pahoehoe flow of Waiakea Stream, younger $\quad 10,320 \pm 70$

Charcoal root at top of ash layer beneath pahoehoe flow; coll from $\mathrm{N}$ bank of $\mathrm{S}$ fork of Waiakea Stream between Hoaka and Alawaena Rds, alt $1000 \mathrm{ft}(305 \mathrm{~m}), 650 \mathrm{~m} \mathrm{~W}$ of $\mathrm{E}$ edge of Piihonua quad $\left(19^{\circ} 39.51^{\prime} \mathrm{N}, 155^{\circ}\right.$ 07.85' W). Coll 1982 by J M Buchanan-Banks. Comment (JMBB): sample dates uppermost of several pahoehoe flows exposed in stream and provides time constraints on ash deposits that overlie and underlie this pahoehoe. Re-analysis of W-4894: 21,900 $\pm 270 \mathrm{yr}$. 


\section{W-4623. Aa flow of Rainbow Falls}

$10,610 \pm 150$

Carbonized reeds at top of $6 \mathrm{~m}$-thick ash dispersed beneath lower rubble of vitric, olivine-phyric aa flow where flow laps up on ash; coll in Wailuku R, alt $440 \mathrm{ft}(134 \mathrm{~m}), 0.8 \mathrm{~km} \mathrm{E}$ of W edge of Hilo quad $\left(19^{\circ} 43.38^{\prime} \mathrm{N}\right.$, $155^{\circ} 07.00^{\prime} \mathrm{W}$ ). Coll 1980 by J M Buchanan-Banks and N G Banks. Comment (JMBB): sample provides new date that, with date for pahoehoe flow of Waianuenue Ave (W-4627, -4971, -4973, -4620, -4977), establishes age control on formation of present Wailuku R channel and Rainbow Falls.

\section{W-4627. Pahoehoe flow of Waianuenue Ave $13,530 \pm 180$}

Crumbly carbonized root and rootlets at top of ash deposit beneath pahoehoe flow; coll $150 \mathrm{~m} \mathrm{~W}$ of Kaumana Dr-Waianuenue Ave intersection, across from Carvalho Park on S side of ave under SW bridge abutment, alt $320 \mathrm{ft}(98 \mathrm{~m})$, Hilo quad $\left(19^{\circ} 43.20^{\prime} \mathrm{N}, 155^{\circ} 06.52^{\prime} \mathrm{W}\right)$. Coll 1980 by N (S Banks and J M Buchanan-Banks. Comment (JMBB): sample dates older, previously unrecognized, surface flow in Hilo, probably same flow as that dated by $\mathrm{W}-4971,-4973,-4620,-4977$, although it contains higher percentage of olivine phenocrysts. Thin overlying ash deposit obscures stratigraphic relationships.

W-4971. Pahoehoe flow of Waianuenue Ave

$14,080 \pm 150$

Carbonized root or tree branch at top of ash layer beneath pahoehoe flow; coll on $\mathrm{N}$ side of ave at $\mathrm{W}$ end of First Protestant Church parking lot, alt $535 \mathrm{ft}(163 \mathrm{~m}), 0.5 \mathrm{~km} \mathrm{E}$ of W boundary of Hilo quad $\left(19^{\circ} 43.23^{\prime} \mathrm{N}, 155^{\circ}\right.$ 07.20' W). Coll 1982 by J M Buchanan-Banks. Comment (JMBB): flow is characterized by surface that crumbles when struck with hammer. Date confirms this lobe to be same flow as that dated by W-4627, $-4973,-4620$, -4977 .

\section{W-4973. Pahoehoe flow of Waianuenue Ave}

$14,370 \pm 190$

Charcoal tree root at top of thick ash deposit beneath pahoehoe flow; coll $200 \mathrm{~m} \mathrm{~N}$ and $700 \mathrm{~m} \mathrm{E}$ of Ainako Ave, in $\mathrm{N}$ side of cut for driveway of pole house on Kacokulani St, alt $610 \mathrm{ft}(186 \mathrm{~m}), 100 \mathrm{~m}$ E of W edge of Hilo quad $\left(19^{\circ} 42.95^{\prime} \mathrm{N}, 155^{\circ} 07.43^{\prime} \mathrm{W}\right)$. Coll 1982 by J M Buchanan-Banks and V C Taylor. Comment (JMBB): date establishes min age for thick ash and Mauna Kea flows that underlie it. Site now covered by masonry retaining wall.

\section{W-4620. Pahoehoe flow of Waianuenue Ave}

$14,500 \pm 200$

Carbonized root and rootlets at top of thick ash beneath pahochoe flow; coll in S bank of Wailuku R, N of Waianuenue Ave off Piikea St, alt $535 \mathrm{ft}(163 \mathrm{~m}), 80 \mathrm{~m} \mathrm{E}$ of W edge of Hilo quad $\left(19^{\circ} 43.32^{\prime} \mathrm{N}, 155^{\circ} 07.45^{\prime} \mathrm{W}\right)$. Coll by J M Buchanan-Banks and N G Banks. Comment (JMBB): flow, $12-$ $14 \mathrm{~m}$ above present river level, occupies channels cut by ancestral river into ash and underlying saprolitic deposits developed on Mauna Kea flows. Date establishes min age for development of this part of Wailuku R channel. 
Charcoal root and rootlets at top of ash layer beneath pahochoe flow; coll $280 \mathrm{~m} \mathrm{~S}$ of Waianuenue Ave, ca $300 \mathrm{~m}$ W of Kaumana Springs, alt $480 \mathrm{ft}$ ( $146 \mathrm{~m})$, Hilo quad $\left(19^{\circ} 43.08^{\prime} \mathrm{N}, 155^{\circ} 07.02^{\prime} \mathrm{W}\right)$. Coll 1982 by J M Buchanan-Banks. Comment ( JMBB): age confirms this to be $\mathrm{S}$ lobe of flow dated by $\mathrm{W}-4627,-4971,-4973,-4620$.

Charcoal coll from two localities at contact between $1-1.5 \mathrm{~m}$-thick ash deposit and overlying pahochoe flow, in Waiakea Stream between Hoaka and Alawacna Rds, Piihonua quad $\left(19^{\circ} 39.51^{\prime}\right.$ and $39.68^{\prime} \mathrm{N}, 155^{\circ} 07.85^{\prime}$ and $\left(07.65^{\prime} \mathrm{W}\right.$ ). Coll 1982 by J M Buchanan-Banks. Comment (JMBB): invalid age as charcoal from two different sites, erroncously thought to be from beneath same flow, were combined. Anomalously old age led to recollection of charcoal for analysis as W-5072 and -5075 .

\section{W-4890. Pahoehoe flow of Waipahoehoe Stream}

$23,840 \pm 600$

Charcoal root coll at top of thin ash layer beneath pahoehoe flow, near base of waterfall, alt $680 \mathrm{ft}(207 \mathrm{~m}), 160 \mathrm{~m} \mathrm{E}$ from W edge of Hilo quad $\left(19^{\circ}\right.$ $\left.41.83^{\prime} \mathrm{N}, 155^{\circ} 07.43^{\prime} \mathrm{W}\right)$. Coll 1980 by J M Buchanan-Banks. Comment ( JMBB): sample dates one of oldest exposed Mauna Loa lava flows in quadrangle and establishes min age for much of ash deposited in quad. At coll site, flow is overlain by pahochoe of 1880-81 eruption, thin ash, pahochoe of Punahoa ahupuaa dated by W-4629, and 3-4m-thick section of ash; flow overlies thin ash layer and another undated pahoehoe from ML.

\section{W-5075. Pahoehoe flow of Waiakea Stream, older}

$24,240 \pm 500$

Charcoal roots and rootlets coll at top of thin ash layer beneath pahoehoe flow, between Hoaka and Alawaena Rds, alt $880 \mathrm{ft}(268 \mathrm{~m}), 180 \mathrm{~m} \mathrm{~W}$ of E edge of Piihonua quad $\left(19^{\circ} 39.68^{\prime} \mathrm{N}, 155^{\circ} 07.65^{\prime} \mathrm{W}\right)$. Coll 1982 by J M Buchanan-Banks. Comment (JMBB): reanalysis of W-4894. Sample dates one of oldest pahochoe flows exposed in Waiakea Stream; comparisons of thin sections establish this flow as distinct from that dated by W-4890. At colln site, flow is overlain by ash, which in turn is overlain by pahoehoe flow dated by $\mathrm{W}-5072$.

\section{ACKNOWLEDGMENTS}

We are indebted to Lea Gargulinski and John McGechin, USGS, Reston, for sample preparation and treatment. The manuscript's consistency and clarity were improved by the thoughtful reviews of D Dzurisin and D Yamaguchi, USGS, Vancouver.

Holcomb, R, Champion, 1), and McWilliams, M, 1986, Dating recent Hawaiian lava flows using palcomagnetic secular variation: Geol Soc America Bull, v 97, p 829-839.

Kelley, M I Spiker, E C, Lipman, P W, Lockwood, J P. Holcomb, R T and Rubin, M, 1979, US Geological Survey, Reston, Virginia, radiocarbon dates XV: Mauna Loa and Kilauea Volcanoes, Hawaii: Radiocarbon, v 21, no. 2, p 306-320. 
Lockwood, J P and Lipman, P W, 1980, Recovery of datable charcoal beneath young lavas: Lessons from Hawaii: Bull Volcanol, v 43, no. 3, p 609-615.

Peterson, D W and Moore, R B, 1987, Geologic history and evolution of geologic concepts, island of Hawaii, in Decker, R W, Wright, T L and Stauffer, P H, eds, Volcanism in Hawaii: US Geol Survey Prof Paper 1350, v 1, p 149-189.

Rubin, M, Gargulinski, L K and McGeehin, J P, 1987, Hawaiian radiocarbon dates, in Decker, R W, Wright, T L and Stauffer, P H, eds, Volcanism in Hawaii: US Geol Survey Prof Paper 1350, v 1, p 213-242.

Rubin, M, Lockwood, J P and Friedman, I, 1987, Effects of volcanic emanations on carbonisotope content of modern plants near Kilauea volcano, in Decker, R W, Wright, T L and Stauffer, P H, eds, Volcanism in Hawaii: US Geol Survey Prof Paper 1350, v 1, p 209 211 